\title{
Blended Learning: Pengembangan dan Implementasinya pada Mata Kuliah Fisiologi Tumbuhan
}

\section{Blended Learning: Development and Implementation of the Course in Plant Physiology}

\author{
Listika Yusi Risniani $^{* 1}$, Arief Husein ${ }^{1}$ \\ ${ }^{1}$ Universitas Muhammadiyah Purwokerto \\ * Email Korespondensi: listikayusirisnani@ump.ac.id \\ doi: $h$ ttp://dx.doi.org/10.29405/ j.bes/3274-834007
}

Received: 04 Desember 2019 | Accepted: 28 Desember 2019 | Published: 31 Desember 2019

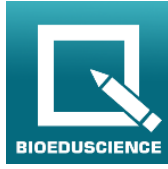

\begin{abstract}
Abstrak
Latar belakang: Perkembangan teknologi informasi dan komunikasi terutama budaya internet dan Cyber Society di kalangan mahasiswa memberikan peluang bagi dosen untuk dapat memanfaatkannya sebagai upaya untuk meningkatkan efektifitas dan efisiensi pembelajaran dan hasil belajar mahasiswa. Salah satu upaya adalah melalui pembelajaran blended learning. Tujuan penelitian ini adalah untuk mengembangkan dan implemetasikan pembelajaran blended learning serta mengetahui dampaknya pada hasil belajar mahasiswa pada kuliah Fisiologi Tumbuhan. Metode: Penelitian ini merupakan penelitian pengembangan dengan menggunakan desain pengembangan ADDIE yang terdiri atas beberapa tahapan yaitu 1) analysis, 2) design, 3) development, 4) implementation, dan 5) evaluation. Populasi dalam penelitian ini adalah seluruh mahasiswa Prodi Pendidikan Biologi semester 3. Teknik pengumpulan data berupa teknis tes (tes pilihan ganda dan tes essay) dan non tes (kuesioner). Teknik analisis data menggunakan teknik analisis deskriptif kuantitatif. Hasil: Hasil Penelitian menunjukkan bahwa pengembangan konten e-learning yang disusun oleh dosen cukup baik. Implementasi blended learning memberikan dampak positif terhadap hasil belajar mahasiswa dengan nilai rata-rata 70,54 (baik) dengan standar deviasi sebesar 3,12. Sebagian besar mahasiswa memiliki persepsi yang positif yaitu sebanyak 66,67-95,24 \% pada aspek layanan belajar, sebanyak 42,56 -100\% mahasiswa pada aspek aksesbilitas, dan 61,9-100\% mahasiswa pada aspek kualitas materi ajar. Kesimpulan: Implemetasi blended learning memberikan hasil belajar kepada mahasiswa secara lebih merata dan dalam kategori baik dan sebagian besar (52,38-100 \%) mahasiswa memberikan penilaian yang positif terhadap pembelajaran blended learning pada aspek layanan belajar, aksesbilitas, dan kualitas materi ajar kecuali dalam hal kesukaannya pada tugas online dan partisipasi diskusi.
\end{abstract}

Kata kunci: Blended learning; Hasil belajar; Persepsi mahasiswa.

\section{Abstract}

Background: The development of information and communication technology especially internet culture and Cyber Society among students provides opportunities for lecturers to be able to use it as an effort to improve the effectiveness and efficiency of learning and student learning outcomes. One effort is through blended learning. The purpose of this study is to develop and implement blended learning and find out its impact on student learning outcomes in the Plant Physiology course. Method: This research is a type of development research using ADDIE development design which consists of several stages, namely 1) analysis, 2) design, 3) development, 4) implementation, and 5) evaluation. The population in this study were all semester 3 Biology Education Department students. Data collection techniques were in the form of technical tests (test questions) and non-tests (questionnaire). Data analysis techniques using quantitative descriptive analysis techniques. Results: The results showed that the development of e-learning content compiled by lecturers was quite good. The implementation of blended learning has a positive impact on student learning outcomes with an average value of 70.54 (good) with a standard deviation of 3.12. Most students have a positive perception that is as much as 66.67 to $95.24 \%$ in aspects of learning services, 
as many as $42.56-100 \%$ of students in the aspect of accessibility, and 61.9-100\% of students in the aspect of quality of teaching materials. Conclusion: The implementation of blended learning gives learning outcomes to students more evenly and in good categories and most (52.38 - 100\%) students give positive assessments of blended learning in aspects of learning services, accessibility, and quality of teaching materials except in his favorite thing about online assignments and discussion participation. to students more evenly and in good categories and most (52.38 - 100\%) students give positive assessments of blended learning in aspects of learning services, accessibility, and quality of teaching materials except in his favorite thing about online assignments and discussion participation.

Keywords Blended learning; Learning outcomes; Student perception

Cara citasi: Risnani, L. Y., \& Husin, A. (2019). Blended Learning: Pengembangan dan Implementasinya pada Mata Kuliah Fisiologi Tumbuhan. BIOEDUSCIENCE: Jurnal Pendidikan Biologi Dan Sains, 3(2): 73-83. Doi: http://dx.doi.org/10.29405/ j.bes/3274-834007

(C) 2019 Oleh authors. Lisensi Bioeduscience, Uhamka, Jakarta. Artikel ini bersifat open access yang didistribusikan di bawah syarat dan ketentuan Creative Commons Attribution (CC-BY) license. (http://creativecommons.org/licenses/by/4.0/).

\section{PENDAHULUAN}

Perkembangan teknologi informasi dan komunikasi terutama teknologi digital yang begitu pesat saat ini telah mempengaruhi dan mengubah berbagai aspek kehidupan manusia. Dunia kehidupan semakin dihubungkan dengan teknologi informasi yang sangat nyata melalui internet. Berkembangnya budaya internet dan Cyber Society yang memadukan antara internet dengan komunikasi selular dengan berbagai inovasi perangkat keras, membuat internet mulai menggantikan model komunikasi kehidupan sosial bahkan mengubah sistem dan nilai budaya serta dimensi spiritual manusia termasuk dikalangan mahasiswa (BNSP, 2010). Hal ini memberikan peluang bagi dosen untuk dapat memanfaatkan budaya internet dan cyber society di kalangan mahasiswa sebagai upaya untuk meningkatkan efektifitas dan efisiensi pembelajaran dan hasil belajar mahasiswa. Model pembelajaran tatap muka di kelas (face-to-face) terlalu kuno sehingga dengan menerapkan $e$ learning akan dapat mengikuti pekembangan zaman dan memberikan hasil yang sesuai dengan harapan serta lebih efektif (Wardani, Nanindya, Toenlioe, \& Wedi, 2018). Blended learning menjadi salah satu inovasi dari model mengajar tradisional yang dianggap masih belum efisien dan sedikit sekali melibatkan siswa dalam aktivitas pembelajaran di kelas.
Model Blended learning adalah model pembelajaran yang mengkombinasi antara pembelajaran tatap muka (face to-face) dengan $e$ learning (Ningsih \& Jayanti, 2016). Melalui blended learning interaksi dan komunikasi antar mahasiswa dan antara dosen dan mahasiswa dapat terus berlangsung dan hal tersebut merupakan daya tarik pembelajaran di era 21 (Wardani et al., 2018).

Pada model blended learning ini dilaksanakan pula perkuliahan tatap muka menggunakan model flipped classroom. Model pembelajaran tersebut dikenal sebagai model "kelas terbalik". Pembelajaran dilaksanakan dengan cara meminimalkan jumlah instruksi langsung di kelas dan memaksimalkan interaksi peserta didik/mahasiswa (Damayanti \& Sutama, 2016). Pada flipped classroom, sebelum datang ke kelas, mahasiswa telah belajar melalui Learning Management System (LMS) yang disusun oleh dosen dalam kelas online (berbasis website) sehingga aktivitas kegiatan di kelas berupa diskusi dan bertukar pikiran/gagasan baik antar teman maupun dosen untuk penyelesaian masalah tertentu (problem solving).

Blended learning memiliki beberapa kelebihan diantaranya adalah a) penyampaian pembelajaran dapat dilaksanakan kapan saja dan dimana saja dengan memanfaatkan sistem jaringan internet, b) peserta didik dapat belajar secara mandiri dengan mempelajari materi yang 
telah tersedia secara online, c) kegiatan diskusi berlangsung secara online/offline dan dapat berlangsung diluar jam pelajaran, d) pengajar atau dosen dapat mengelola dan mengontrol pembelajaran yang dilakukan peserta didik diluar jam pelajaran, e) pengajar dapat meminta peserta didik mengkaji materi dan menyiapkan tugas-tugas pendukung sebelum pembelajaran tatap muka berlangsung, f) pengajar dapat menyelenggarakan kuis, memberikan balikan, dan memanfaatkan hasil tes dengan efektif, g) peserta didik dapat saling berbagi file dengan peserta didik lainnya, h) pembelajaran menjadi luwes dan tidak kaku (Husamah, 2014; Widiara, 2018). Melalui pembelajaran berbasis website memungkinkan mahasiswa untuk dapat belajar dengan mandiri, menyelesaikan tes tutorial, diskusi, chatting, dan mengerjakan soal evaluasi melalui media website. Apabila didesain dengan baik pembelajaran berbasis website ini akan mampu meningkatkan kemampuan mahasiswa pada berbagai aspek (Nur, 2017).

Pada model blended learning, dosen dapat mengunggah materi untuk dipelajari mahasiswa dalam berbagai bentuk media digital seperti bentuk format Word, PDF, PowerPoint, Video (Kusumaningrum \& Marpanaji, 2014). Salah satu media digital yang paling efektif digunakan untuk meningkatkan pemahaman dan hasil belajar mahasiswa salah satunya adalah multimedia. Multimedia merupakan gabungan dari beberapa media yaitu gambar, suara, animasi, video dan lain sebagainya (Nataliani, Jampel, \& Suartama, 2014). Multimedia yang dikembangkan dalam penelitian ini yaitu berupa video.

Materi fisiologi tumbuhan mempelajari tentang berbagai macam proses fisiologi yang terjadi dalam tubuh tumbuhan yang sebagian besar tidak dapat dilihat secara langsung oleh mahasiswa. Materi tersebut seperti proses difusi dan osmosis yang terjadi dalam tubuh tumbuhan, naiknya air dan mineral dalam tubuh tumbuhan, proses transpirasi, fotosintesis dan sebagainya. Alokasi 150 menit untuk pembelajaran tatap muka dirasa kurang untuk digunakan berdiskusi masalah berkaitan dengan fisiologi. Berdasarkan pengalaman pembelajaran pada tahun-tahun sebelumnya, proses diskusi sering kali tidak selesai sedangkan waktu yang disedikan telah habis. Hal ini menyebabkan materi tidak dapat dibahas secara tuntas dan menyebabkan mahasiswa kesulitan untuk memahami materi. Hal ini dibuktikan sebagian besar mahasiswa memperoleh nilai yang kurang memuaskan diakhir semester. Salah satu strategi untuk menyelesaikan permasalahan adalah dengan menggunakan blended learning berbantuan multimedia berupa video.

Pemanfaatan multimedia berupa video menyediakan peluang bagi dosen untuk mengembangkan sumber informasi yang tidak lagi terbatas pada teks dari buku semata tetapi lebih luas dari itu. Teknologi multimedia mampu mengintegrasikan teks, grafik, animasi, dan audio sehingga diharapkan membantu siswa lebih mudah dapat menyerap informasi secara cepat dan efisien. Pemanfaatan multimedia video akan membantu seseorang untuk memahami pesan pembelajaran secara lebih bermakna sehingga informasi atau materi yang disampaikan dapat dipahami secara utuh dan tersimpan dalam memori jangka Panjang (Agustriana, 2014).

Pemanfaatan multimedia dalam pembelajaran telah banyak dilaporkan mampu meningkatkan minat dan motivasi dan hasil belajar peserta didik dari mulai tingkat sekolah dasar hingga perguruan tinggi (Ali, 2009; Prawiro \& Irawan, 2012). Hasil penelitian lain tentang implementasi e-learning dengan berbantuan multimedia dilaporkan secara signifikan dapat meningkatkan hasil belajar siswa (Kusumaningrum \& Marpanaji, 2014) Menurut Heinze (2008) beberapa penelitian menunjukkan bahwa blended learning dapat meningkatkan hasil belajar sama dengan atau lebih tinggi dari mahasiswa yang belajar secara konvensional atau sepenuhnya online, meskipun tingkat keberhasilan bervariasi antara disiplin ilmu (Bibi \& Jati, 2015).

Berdasarkan latar belakang diatas maka perlu dikembangkan dan perlu adanya 
implementasi pembelajaran Blended learning dengan berbantuan multimedia pada mata kuliah Fisiologi Tumbuhan.

\section{MATERI DAN METODE}

\section{Lingkup Penelitian}

Penelitian ini merupakan penelitian pengembangan untuk mengembangkan pembelajaran blended learning pada mata kuliah fisiologi tumbuhan (3 sks) pada mahasiswa semester 3 Program Studi Pendidikan Biologi Universitas Muhammadiyah Purwokerto. Penelitian ini dilakukan pada bulan Juli November 2019. Diskusi dengan dosen tim juga dilakukan untuk memilih pokok bahasan yang akan dibelajarkan dalam e-learning dan pokok bahasan yang akan dibelajarkan dengan tatap muka. Populasi yang digunakan dalam penelitian ini adalah seluruh mahasiswa program studi Pendidikan biologi UMP yang berjumlah 28 mahasiswa

\section{Desain penelitian}

Penelitian ini menggunakan desain pengembangan dengan model ADDIE yang terdiri atas beberapa tahapan yaitu 1) analysis, 2) design, 3) development, 4) implementation, dan 5) evaluation (Aldoobie, 2015).

\section{Prosedur Penelitian}

Secara rinci, prosedur pengembangan konten pembelajaran e-learning sebagai salah satu bagian dari blended learning melalui tahapan sebagai berikut:

\section{Analysis}

Analisis dilakukan terhadap tiga hal yaitu a) analisis mata kuliah yang akan digunakan dalam pembelajaran e-learning, b) analisis terhadap mahasiswa, dan c) analisis tujuan instruksional. Analisis terhadap mata kuliah meliputi analisis karakteristik materi mata kuliah, analisis capaian pembelajaran mata kuliah dan analisis capaian pembelajaran setiap pertemuan. Analisis terhadap mahasiswa meliputi pengalaman, kemampuan, keterampilan, permasalahan dan hal-hal yang sekiranya dibutuhkan oleh peserta didik dalam pembelajaran blended learning. Peneliti menganalisis dan mengidentifikasi tujuan instruksional mata kuliah yang akan di sampaikan secara $e$ learning (fisiologi tumbuhan) dan mengembangkan indikator pembelajarannya

2. Design

Pada tahap desain, disusun Peta Program Pembelajaran yang berpedoman pada Rencana Pembelajaran Semester (RPS) di kelas konvensional. Peta Program pembelajaran $e$ learning disusun dengan memperhatikan : a) identitas mata kuliah, b) capaian pembelajaran yang meliputi sikap, keterampilan umum, keterampilan khusus, dan pengetahuan, c) deskripsi mata kuliah yang meliputi sesi, sub capaian pembelajaran strategi pembelajaran, objek pembelajaran dan assesment

Selain Peta Program Pembelajaran, didesain juga RPS Blended Learning. RPS Blended Learning disusun dengan berpedoman pada RPS pembelajaran di kelas konvensional dengan memperhatikan komponen yaitu a) identitas mata kuliah dan dosen pengampu, b) capaian pembelajaran, c) capaian mata kuliah (CPMK), d) pertemuan, kemampuan akhir yang diharapkan, bahan kajian, metode pembelajaran, alokasi waktu, pengalaman belajar mahasiswa, kriteria penilaian dan bobot nilai.

Pada tahap ini didesain pula multimedia dalam bentuk video yang akan digunakan sebagai media dalam pembelajaran e-learning

\section{Development}

Pengembangan konten pembelajaran elearning sebagai bagian dari blended learning dilakukan pada LMS Moodle Universitas Muhammadiyah Purwokerto (UMP). Pada tahap ini meliputi : 1) mengembangkan video konten materi fisiologi tumbuhan, 2) membuat akun e-learning, 3) pengembangan alur pembelajaran e-learning dan 4) pembuatan konten pembelajaran e-learning.

Pengembangan video oleh dosen menggunakan aplikasi edit video Wonderfull Filmora9. Sebelum pembuatan akun nama dosen dan mata kuliah harus didaftarkan dulu 
pada LMS Moodle Universitas. Pembuatan akun dilakukan untuk kepentingan log in pada LMS Moodle Universitas (onclass.ump.ac.id).

Pengembangan alur pembelajan $e$ learning yaitu mengembangkan bagaimana pembelajaran online itu akan disampaikan. Alur pembelajaran yang dirancang pada mata kuliah e-learning fisiologi tumbuhan adalah a) menyampaikan ucapan selamat datang dan salam , b) menyampaikan aturan pelaksanaan perkuliahan, c) menyampaikan capaian pembelajaran, d) mengunggah file RPS Blended Learning, e) menyusun perkuliahan pada masing-masing pertemuan.

Pembuatan konten e-learning dilaksanakan dengan mengunggah berbagai file yang dibutuhkan selama perkuliahan online. Konten Pembelajaran dibuat dengan cara melakukan penambahan konten dengan klik button "Add an activity or resource" (Gambar 1)

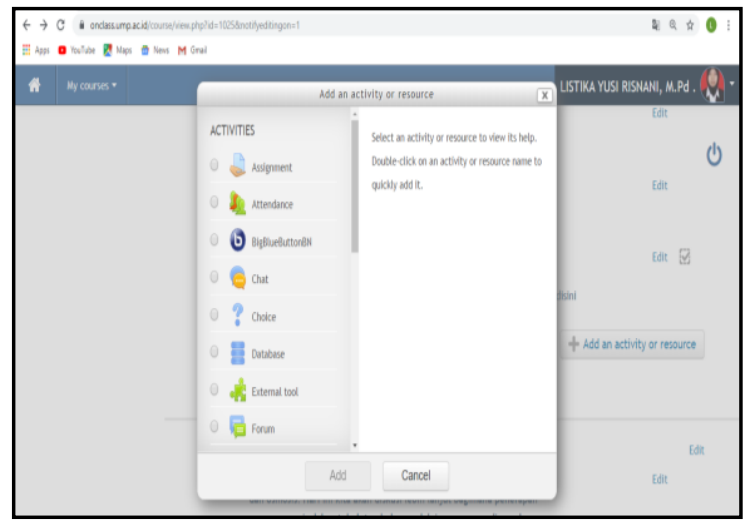

Gambar 1. Pembuatan Konten E-Learning

Berbagai jenis konten materi dan resource yang digunakan dalam e-learning ini meliputi Forum (Gambar 2), Assigment, Chat, File, Book, Label dan URL.

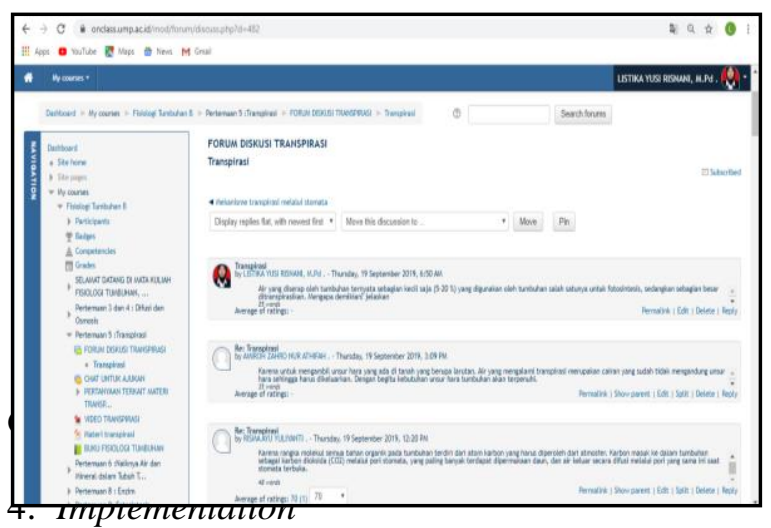

Pada tahap implementasi beberapa hal yang dilakukan yaitu a) perkuliahan berbasis $e$ -learning, b) monitoring perkuliahan, c) melaksanakan penilaian mahasiswa selama $e$ learning. Perkuliahan belended learning (3 SKS) dilaksanakan sebanyak 5 kali pertemuan dengan 1 pertemuan flip classroom dari total pertemuan sebanyak 22 kali (100 menit/pertemuan).

\section{Evaluation}

Pada tahap ini dilakukan evaluasi oleh validator yang tergabung dalam tim ahli program hibah SCL berbasis TIK tingkat Fakultas. Hal ini dilakukan untuk memonitor sejauh mana pelaksanakan e-learning sudah dilaksanakan dosen, menilai kesesuaian pelaksanaan e-learning dengan Peta Program Pembelajaran dan RPS Blended learning. Evaluasi dilaksanakan juga untuk menggali kesulitan atau permasalahan yang dihadapi dosen dalam pembelajaran e-learning, dan memberikan masukkan atas konten pembelajaran e-learning yang disusun oleh dosen.

\section{Pengumpulan Data dan Analisis Data}

Data dalam penelitian ini berupa data hasil belajar mahasiswa selama pembelajaran blended learning dan data persepsi mahasiswa terhadap blended learning. Teknik pengumpulan data dalam penelitian ini menggunakan teknik tes dan non-tes (pengisian kuesioner). Teknik tes menggunakan tes pilihan ganda dan tes essay dilakukan pada setiap pertemuan dalam blended learning. Tes digunakan untuk mengetahui penguasaan materi oleh mahasiswa selama pembelajaran blended learning. Teknik non tes menggunakan kuesioner digunakan untuk mengetahui persepsi dan respon mahasiswa terhadap pembelajaran blended learning. Kuesioner disusun untuk menggali persepsi mahasiswa terhadap meliputi 3 aspek yaitu layanan belajar (8 item), aksesbilitas sumber belajar (8 item) dan kualitas materi ajar (9 item).

Teknik analisis data yang digunakan adalah analisis deskriptif kuantitatif. Teknik deskriptif kuantitatif digunakan untuk menganalisis data hasil tes penguasaan materi 
mahasiswa dan menganalisis data persepsi mahasiswa terhadap pembelajaran blended leraning.

\section{HASIL}

Pengembangan konten e-learning dilakukan pada lima kali pertemuan pada a) topik potensial air, potensial kimia dan potensial osmotic, b) difusi dan osmosis, c) transpirasi, d) mekanisme naiknya air pada tumbuhan, dan e) enzim. Berikut adalah halaman log in e-learning bagi dosen.

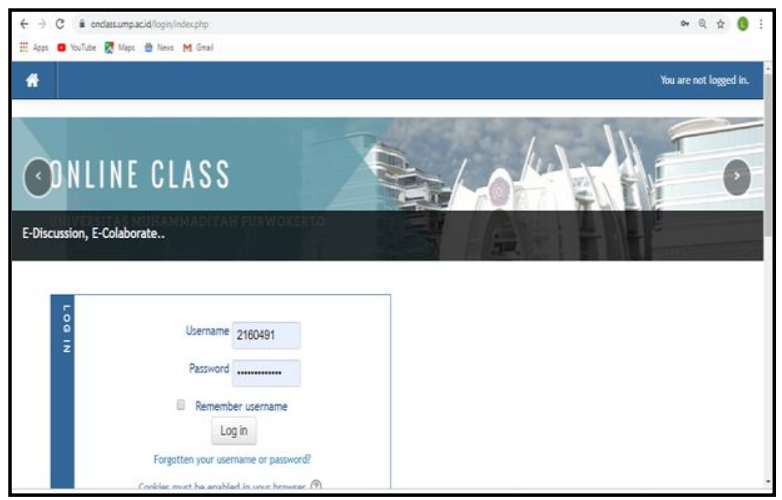

Gambar 3. Halaman Log In Ke Sistem E-Learning Bagi Dosen

Berbagai jenis konten materi dan resource yang digunakan dalam e-learning ini meliputi Forum (Gambar 4), Assigment, Chat, File, Book, Label dan URL.

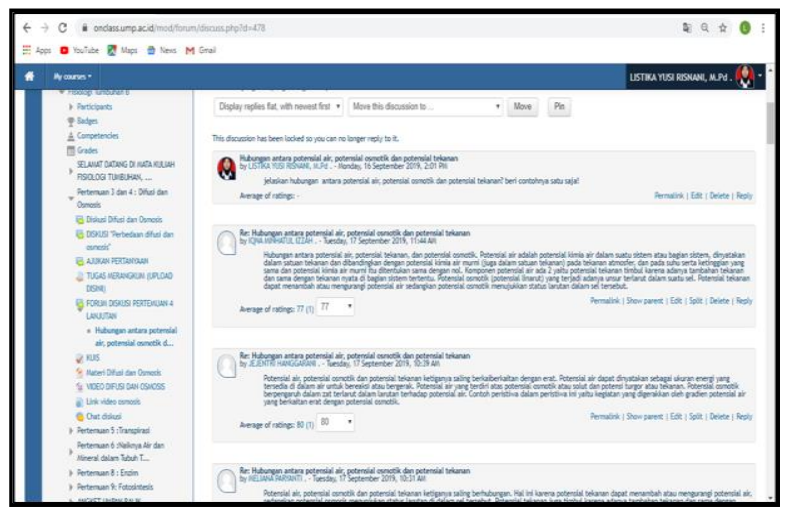

Gambar 4. Forum Diskusi Pada Pertemuan 1

Selama e-learning dilakukan tes dalam bentuk forum diskusi, chat, atau kuis (Gambar 5).

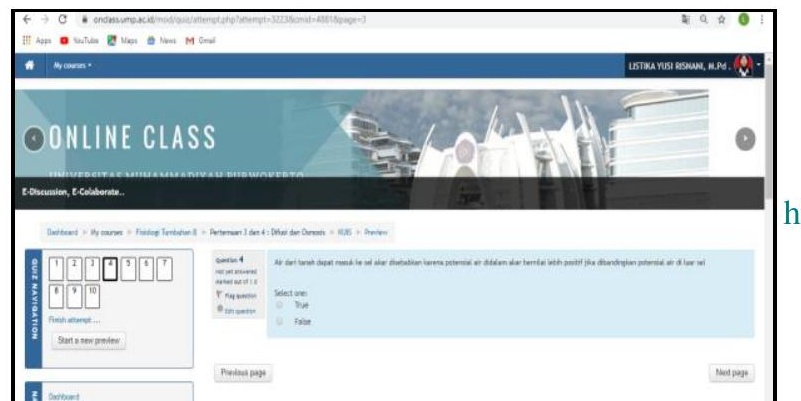

Gambar 5. Tampilan Kuis Sistem Benar Salah Pada LMS Moodle

Hasil belajar mahasiswa yang digambarkan oleh nilai rata-rata pada setiap pertemuan yaitu 70,54 (baik) dengan standar deviasi sebesar 3,12. Nilai standar deviasi yang kecil menunjukkan bahwa nilai yang diperoleh mahasiswa cenderung homogen.

Persepsi mahasiswa terhadap pembelajaran blended learning digali dengan memberikan link kuesioner kepada mahasiswa melalui LMS Moodle. Hasil analisis kuesioner menunjukkan bahwa sebagian besar mahasiswa $(66,67-95,24$ $\%)$ menyatakan memperoleh layanan belajar dengan baik pada pembelajaran blended learning. Hal ini dibuktikan sebanyak 90,48 \% mahasiswa menyatakan bahwa pembelajaran blended learning yang dilakukan dosen pada sistem https://onclass.ump.ac.id mudah diikuti dan digunakan, sebanyak 95,24\% menyatakan bahwa pembelajaran blended-learning yang dilakukan dosen disajikan dengan susunan konten yang menarik, sebanyak 95,24 \% mahasiswa menyatakan bahwa tingkat partisipasi dalam pelaksanaan pembelajaran blended learning dalam kategori baik sampai dengan sangat baik, sebanyak $66,67 \%$ mahasiswa menyatakan bahwa pembelajaran blended-learning yang dilakukan dosen memiliki kemampuan mengontrol kemajuan belajar mahasiswa, sebanyak 76,19\% mahasiswa menyatakan bahwa pembelajaran blended learning yang dilakukan dosen memiliki kemampuan merekam aktivitas belajar mahasiswa dan sebanyak 80,95 mahasiswa menyatakan bahwa pembelajaran blended learning menyenangkan (Gambar 6).

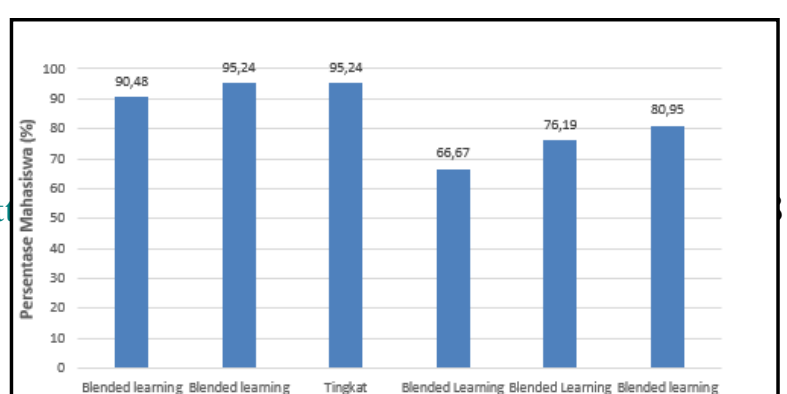


Gambar 6. Persepsi Mahasiswa dalam Aspek Layanan Belajar Model Blended Learning

Berdasarkan analisis angket terhadap aspek layanan belajar mahasiswa juga diperoleh informasi mengenai bagian yang paling disukai dan tidak disukai oleh mahasiswa selama pembelajaran Blended Learning. Hal yang paling disukai mahasiswa dalam pembelajaran blended learning dari persentase tinggi hingga terendah secara berturut-turut adalah presentasi dan diskusi $(42,86 \%)$, penggunaan media $(28,57 \%)$, bagian online $(14,29 \%)$ semua bagian $(9,52 \%)$ dan lainnya yaitu mahasiswa langsung mendapatkan materi seperti slide presentasi dosen, video sehingga memudahkan mahasiswa untuk belajar lagi dirumah (4,78\%; Gambar 7A). Bagian yang paling tidak disukai mahasiswa pada pembelajaran Blended Learning dari persentase tertinggi hingga terendah secara berturut-turut adalah manajemen waktu $(57,14 \%)$, akses partisipasi online $(19,05)$, tidak ada hal yang mereka tidak sukai dari pembelajaran blended learning $(14,29 \%)$ dan koneksi internet yang jelek $(9,52 \%$; Gambar 7B).

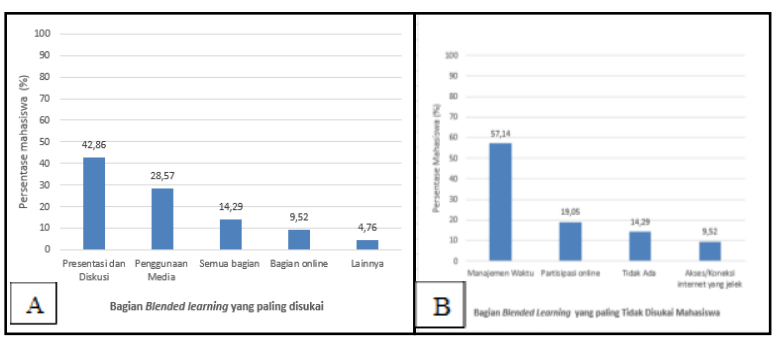

Gambar 7. Respon Mahasiswa terhadap Bagian yang Paling disukai (A) dan Tidak Disukai Pada Model Blended Learning (B)

Hasil analisis kuesioner pada aspek aksesbilitas menunjukkan bahwa seluruh mahasiswa (100\%) menyatakan berkomentar saat forum diskusi online dengan tingkat partisipasi sering dan sangat sering (2 kali) dan sangat sering (>3 kali). Selain itu seluruh mahasiswa $(100 \%)$ menyatakan bahwa pembelajaran blended learning memudahkan mahasiswa dalam mengakses sumber belajar yang dibagikan dosen. Sekitar 50\% mahasiswa memberikan tanggapan bahwa partisipasi diskusi mereka sama secara online sama dengan pembelajaran di kelas (57, 13\%), pembelajaran blended learning memudahkan mahasiswa diskusi dengan mahasiswa lain $(52,38 \%)$ dan dosen $(57,14 \%)$, dan penugasan secara online lebih mudah dikelola $(52,38 \%)$. Selain itu mahasiswa $(47,61$ $\%$ menyatakan menyukai tugas online dan memberikan tanggapan bahwa partisipasi dalam diskusi online lebih banyak jika dibandingkan dengan pembelajaran di kelas konvensional (42, $56 \%$; Gambar 8).

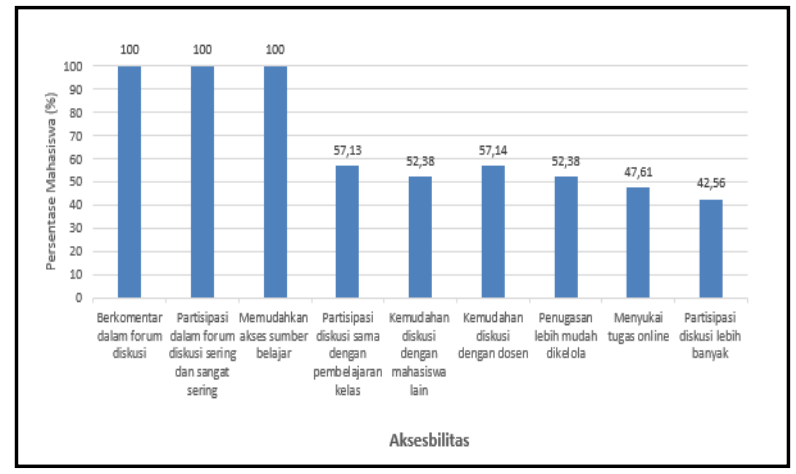

Gambar 8. Persepsi Mahasiswa terhadap Aksesbilitas Pembelajaran Blended Learning

Hasil analisis kuesioner pada aspek kualitas materi ajar menunjukkan bahwa sebagian besar (90-100\%) mahasiswa memberikan penilaian baik terhadap materi yang disajikan dosen melalui model Blended learninga kecuali dalam aspek penggunaan bahasa sederhana dan mudah dipahami yaitu 61,9\% (Gambar 9). 


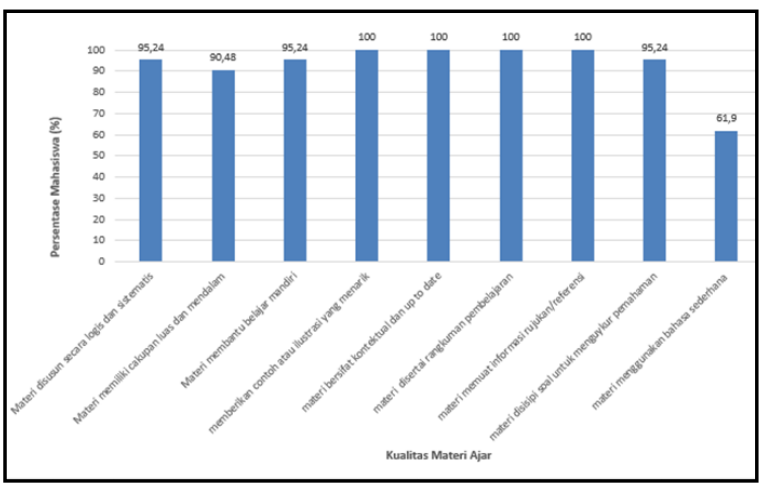

Gambar 9. Persepsi Mahasiswa Terhadap Kualitas Materi Ajar yang Disajikan oleh Dosen

\section{PEMBAHASAN}

Hasil penelitian menunjukkan bahwa ratarata hasil belajar mahasiswa dalam pembelajaran blended learning yaitu 70,54 dalam kategori baik dan dengan standar deviasi 3,12. Standar deviasi yang relative kecil menunjukkan bahwa hasil belajar mahasiswa relative homogen/sama.

Hasil penelitian yang serupa dilaporkan oleh Bibi \& Jati (2015), bahwa tingkat pemahaman mahasiswa Program Studi Pendidikan Teknologi Informasi dan Komputer STKIP PGRI Pontianak untuk mata kuliah Algoritma dan Pemrograman mengalami peningkatan secara signifikan melalui penerapan blended learning dibanding kelas konvensional. Hasil penelitian lain juga dilaporkan bahwa implementasi blended learning memberikan hasil belajar yang baik pada mahasiswa semester IV pada materi persamaan diferensial (Ningsih \& Jayanti, 2016).

Implementasi blended learning pada mata kuliah Fisiologi Tumbuhan diperoleh hasil belajar yang tinggi diduga karena blended learning menggabungkan e-learning dengan tatap muka. Pada e-learning, mahasiswa dilatih untuk belajar mandiri tanpa menunggu perintah dari dosen dengan bekal sumber belajar yang diunggah dosen pada kelas online. Hal ini didukung oleh hasil kuesioner yang menyatakan bahwa mahasiswa dipermudah untuk mengakses sumber belajar (100\%) dan materi yang diunggah dosen mendukung belajar mandiri $(95 \%)$. Selain itu melalui pembelajaran e-learning sebagai bagian dari blended learning dapat mengatasi kendala kurangnya waktu belajar bagi mahasiswa.

Mata kuliah Fisiologi Tumbuhan dengan bobot 3 sks, memerlukan waktu perkuliahan tatap muka 150 menit/per minggu. Waktu perkuliahan tatap muka biasanya hanya cukup untuk dosen menjelaskan materi, jarang sekali cukup waktu untuk memberikan mahasiswa kesempatan diskusi dan mengerjakan soal/kuis sebagai latihan. Keterlibatan mahasiswa dalam belajar menjadi terbatas menyebabkan informasi/materi yang disampaikan dosen menjadi kurang dipahami dengan baik. Melalui pembelajaran e-learning ini dikembangkan forum diskusi sehingga seluruh mahasiswa terlibat dalam diskusi topik tertentu. Meskipun diskusi bukan metode baru di kalangan mahasiswa akan tetapi di dalam diskusi melibatkan interaksi sosial dan interaksi intelektual.

Pada perkuliahan tatap muka, sering terjadi diskusi berakhir pada keterbatasan ruang dan waktu. Pada saat yang sama mahasiswa masih terlalu dini untuk mencapai titik kulminasi dalam lingkup intelektual perihal kajian yang sedang dibahas. Pola-pola seperti ini secara tidak langsung akan memberikan implikasi pada sikap dan perilaku yang stagnan dan mudah kehilangan informasi dan penguasaan terhadap materi menjadi berkurang (Sulistiono, 2019). Pada pembelajaran e-learning jangkauan diskusi menjadi lebih luas dan lebih mendalam. Interaksi mahasiswa dengan mahasiswa atau dengan dosen tidak dibatasi oleh ruang dan waktu, artinya ruang dan waktu belajar mahasiswa yang tersedia untuk aktivitas diskusi menjadi lebih longgar sehingga penguasaan materi dan hasil belajar dapat meningkat.

Hasil belajar mahasiswa yang relative merata atau homogen diduga karena forum diskusi yang dikembangkan pada setiap pertemuan dalam e-learning juga telah berhasil meningkatkan partisipasi mahasiswa (100\%) dalam bertanya atau menanggapi termasuk pada mahasiswa yang terkadang enggan atau malu pada perkuliahan tatap muka. Hal ini didukung 
oleh hasil angket yang menyatakan bahwa seluruh mahasiswa selalu berpartisipasi dalam forum diskusi dengan intensitas sering dan sering sekali.

Penggunaan multimedia berupa video dalam pembelajaran blended learning yang disusun sendiri oleh dosen maupun di download dari youtube juga akan mempengaruhi pemahaman mahasiswa terhadap materi yang disampaikan. Menurut Yazdi \& Zandkarimi (2013), pembelajaran dengan menggunakan media audio visual seperti video dapat memotivasi dan meningkatkan hasil pembelajaran. Hasil penelitian oleh Barak, Ashkar \& Dori (2011) juga mengungkapkan bahwa penggunaan multimedia dapat meningkatkan motivasi belajar yang berkorelasi positif dengan kemampuan berpikir. Motivasi pada penelitian ini ditunjukkan dengan partisipasi yang baik, ketertarikan, memainkannya berulangulang, kesungguhan dalam setiap kegiatan dan selama belajar tidak berbicara di luar topik pembelajaran selama kegiatan diskusi berlangsung baik pada forum diskusi online maupun forum diskusi tatap muka.

Perkuliahan dengan blended learning dilakukan dengan mengkombinasikan e-learning dan tatap muka. Pemantauan aktivitas belajar yang dilakukan pada saat perkuliahan tatap muka memiliki peranan yang sangat penting dalam menentukan apakah e-learning telah terlaksana dengan baik atau tidak (Ningsih \& Jayanti, 2016). Kuliah tatap muka memberikan kesempatan kepada dosen untuk memverifikasi tanggapan/jawaban yang diberikan mahasiswa pada e-learning. Dosen dapat memeriksa apakah tanggapan/jawaban mahasiswa merupakan hasil pemikirannya atau hasil 'copy paste' dari internet atau teman lain. Sistem penilaian pada model blended learning dilakukan selama proses pembelajaran. Hal ini akan dapat memberikan gambaran kepada dosen mengenai kemampuan mahasiswa secara lebih representative. Berdasarkan hasil penilaian selama proses ini, dosen dapat mengambil tindakan dengan segera, misalnya dengan memberikan penjelasan pemahaman materi kepada mahasiswa yang kurang mampu, dan memberikan pengayaan materi kepada mahasiswa yang memiliki kemampuan lebih tinggi sehingga hasil belajar mahasiswa dapat merata dan baik. Pada perkuliahan e-learning menyediakan latihan soal dan kuis yang feedback-nya yaitu berupa skor dapat langsung diperoleh termasuk jawaban soal yang benar dan salah. Hal ini dapat membantu mahasiswa untuk mengetahui kelemahan atau kesulitan materi yang mereka hadapi sehingga memotivasi mahasiswa untuk belajar lebih giat untuk mencapai pemahaman dan hasil belajar yang baik.

Hasil penelitian menunjukkan bahwa Sebagian besar (52-100 \%) mahasiswa memberikan penilaian yang positif terhadap pembelajaran blended learning pada aspek layanan belajar, aksesbilitas, dan kualitas materi ajar. Hasil penelitian ini mendukung hasil penelitian sebelumnya yang menunjukkan bahwa sekitar $89 \%$ mahasiswa menyatakan setuju dengan diterapkannya blended learning pada berbagai mata kuliah di Prodi Pendidikan Biologi UNS (Sugiharto, 2015). Hasil penelitian serupa dilaporkan oleh Koharudin (2004) bahwa mahasiswa jurusan Teknik dan Sains Universitas Teknologi Malaysia (UTM) memberikan respon yang positif terhadap pembelajaran e-learning. Meskipun terlihat merepotkan, pembelajaran blended learning memberikan pengalaman belajar baru dan menarik bagi mahasiswa. Hal ini didukung oleh hasil kuesioner bahwa sebanyak $80,95 \%$ mahasiswa menyatakan bahwa pembelajaran blended learning menyenangkan bagi mereka.

Keberhasilan pembelajaran blended learning tidak serta merta terjadi secara otomatis, faktor penting yang mempengaruhi keberhasilan blended learning yaitu desain instruksional terkait bagaiman cara terbaik untuk memanfaatkan fitur-fitur teknologi baik dalam LMS Moodle maupun perkuliahan tatap muka dengan mempertimbangkan aspek pedagogi. Selain itu cara dosen untuk memfasilitasi 
interaksi antara mahasiswa, cara memotivasi mahasiswa, serta menentukan materi yang akan disampaikan melalui e-learning atau melalui tatap muka turut berperan penting pada keberhasilan pembelajaran blended learning.

Pembelajaran blended learning sangat potensial untuk dikembangkan di Prodi Pendidikan Biologi Universitas Muhammadiyah Purwokerto (UMP) pada khususnya maupun Fakultas Keguruan dan Ilmu Pendidikan pada umumnya. Hal ini didukung oleh adanya sarana akses internet melalui wifi (hotspot) yang ada pada hampir setiap ruang dan gedung yang ada di Prodi Pendidikan Biologi khususnya dan FKIP UMP pada umumnya. Potensi pengembangan blended learning tersebut juga didukung oleh adanya faktor-faktor lain antara lain ketersediaan bandwith yang cukup besar di UMP, adanya IT Center dalam bentuk Biro Teknologi Informasi dan Komunikasi (BTIK) tingkat Universitas, serta unit khusus yang menangani e-learning tingkat Universitas dibawah LPMPAI Universitas.

\section{KESIMPULAN}

Pengembangan pembelajaran $e$ learning sebagai bagian dari blended learning dikembangkan dengan model ADDIE efektif untuk digunakan dalam pembelajaran blended learning mata kuliah Fisiologi Tumbuhan. Implemetasi blended learning memberikan hasil belajar kepada mahasiswa secara lebih merata dan dalam kategori baik. Sebagian besar (52,38-100 \%) mahasiswa memberikan penilaian yang positif terhadap pembelajaran blended learning pada aspek layanan belajar, aksesbilitas, dan kualitas materi ajar kecuali dalam hal kesukaannya pada tugas online dan partisipasi diskusi.

\section{UCAPAN TERIMA KASIH}

Terimakasih yang setulus-tulusnya penulis ucapkan kepada Dirjen Belmawa Kemenristek Dikti yang telah membiayai kegiatan ini. Terimakasih juga penulis sampaikan kepada panitia program bantuan pembelajaran Student Center Learning (SCL) tahun 2019 yang telah memfasilitasi dan memberikan banyak masukan demi terselengaranya penelitian ini.

\section{REFERENSI}

Agustriana, E. (2014). Efektivitas Penggunaan Video Pembelajaran untuk Meningkatkan Hasil Belajar Ekonomi Siswa Sma. Jurnal Pendidikan Dan Pembelajaran Khatulistiwa, 3(8), 1-12.

Aldoobie, N. (2015). ADDIE Model. American International Journal of Contemporary Research, 5(6), 68-72.

Ali, M. (2009). Pengembangan Media Pembelajaran Interaktif Mata Kuliah Medan Elektromagnetik. Jurnal Edukasi Elektro, 5(1), 11-18.

Badan Standar Nasional Pendidikan (BNSP). (2010). Paradigma Pendidikan Nasional Abad XXI versi 1.0. Jakarta: BNSP.

Barak, M., Ashkar, T., \& Dori, Y. J. (2011). Computers \& Education Learning science via animated movies: Its effect on students , thinking and motivation. Computers \& Education, 56(3), 839-846. https://doi.org/10.1016/j.compedu.2010.10.025

Bibi, S., \& Jati, H. (2015). Efektivitas Model Blended Learning Terhadap Kuliah Algoritma Dan Pemrograman. Jurnal Pendidikan Vokasi, 5(2), 74-87.

Damayanti, H. N., \& Sutama, S. (2016). Efektivitas Flipped Classroom Terhadap Sikap Dan Ketrampilan Belajar Matematika Di SMK. Jurnal Manajemen Pendidikan, 11(1), 1-7. https://doi.org/10.23917/jmp.v11i1.1799

Heinze, A. (2008). Blended learning: An interpretive action reseach study. In Disertasi doktor, tidak diterbitkan. Salford, UK: University of Salford.

Husamah. (2014). Pembelajaran Bauran (Blended learning) Terampil Memadukan Keunggulan Pembelajaran Face-To-Face, E-learning OfflineOnline, dan Mobile Learning. Jakarta: Prestasi Pustaka.

Koharudin, M. (2004). Perkembangan, pembangunan dan penerimaan e-pembelajaran di institusi pengajian tinggi malaysia. Jurnal Teknologi, $41(\mathrm{E}), 55-71$.

Kusumaningrum, D. A., \& Marpanaji, E. (2014). Pengembangan E-Learning dengan Pendekatan Teori Kognitif Multimedia Pembelajaran di Jurusan TKJ SMK Muhammadiyah 2 Yogyakarta. Jurnal Inovasi Teknologi Pendidikan, 1(1), 28-39. 
Nataliani, N. W., Jampel, I. N., \& Suartama, I. K. (2014). Pengembangan Multimedia Pembelajaran Mata Pelajaran IPS Kelas VII Semester Genap di SMP Negeri 2 Tegallalang. Journal Edutech Universitas Pendidikan Ganesha, 2(1), 1-12.

Ningsih, Y. L., \& Jayanti. (2016). Hasil Belajar Mahasiswa Melalui Penerapan Model Blended Learning Pada Mata Kuliah Persamaan Diferensial. Jurnal Pendidikan Matematika, 2(1), $1-11$.

Nur, M. D. M. (2017). Pengaruh Strategi Pembelajaran Fisika Berbasis Website Terhadap Hasil Belajar pada Siswa yang Memiliki SelfRegulated learning (SRL) yang Berbeda. Edcomtech: Jurnal Kajian Teknologi Pendidikan, 2(1), 65-76.

Prawiro, S. A., \& Irawan, H. (2012). Perancangan Media Pembelajaran Interaktif Ilmu Pengetahuan Alam Untuk Siswa Kelas 4 SD dengan Metode Learning The Actual Object. Jurnal Sains Dan Seni ITS, 1(1), 28-33.

Sugiharto, B. (2015). Profil Pemanfaatan Teknologi Informasi dan Komunikasi serta Potensi Pengembangan Blended Learning pada Mahasiswa Prodi Pendidikan Biologi FKIP UNS. Seminar Nasional XII Pendidikan Biologi FKIP UNS, 12(1), 611-617.

Sulistiono, M. (2019). Implementasi Hybrid Learning Menggunakan Aplikasi Edmodo Pada Matakuliah Metode Penelitian Kualitatif. Jurnal Ilmiah Pendidikan Dasar Islam, 1(1), 57-67.

Wardani, D. N., Nanindya, D., Toenlioe, A. J. E., \& Wedi, A. (2018). Daya Tarik Pembelajaran di Era 21 dengan Blended learning. JKTP, 1(1), 1318.

Widiara, I. K. (2018). Blended Learning Sebagai Alternatif Pembelajaran Di Era Digital. PURWADITA, 2(2), 50-56.

Yazdi, S. M., \& Zandkarimi, G. (2013). The Impact of E-Learning on some Psychological Dimensions and Academic Achievement. International Journal of Education and Learning, 2(2), 49-56. 